\title{
IMPACT OF LOAD RETENTION ON AIRCRAFT ENGINE PARTS UNDER REAL FLIGHT CYCLE CONDITIONS IN SERVICE LIFE MONITORING
}

\author{
Sergiy Yepifanov* (D) 0000-0003-0533-9524 \\ Andrii Brunak (iD 0000-0003-2505-1501 \\ Department of Aircraft Engine Design, Faculty of Aviation Engines, National Aerospace University \\ "Kharkiv Aviation Institute", 17 Chkalova St., Kharkiv, Ukraine \\ *s.yepifanov@khai.edu
}

\begin{abstract}
One of the major problems in the development of algorithms for monitoring the life of aircraft gas turbine engines is that the character of loading in real flight cycles is crucially different from the character of the static and dynamic loading during the testing of samples. This paper proposes a method for taking into account the effect of retentions at maximum stresses and cycle temperatures on the low-cycle fatigue (LCF) of the heat-resistant alloys used in engine parts. Regularities in repeated-static loading (RSL) are used in combination with the method of linear accumulation of damage due to the LCF and RSL, with retentions of a variable length. A non-linear equation is derived for the summation of these damages, the solution of which determines the durability (life) of the part while taking into account the retention duration. The theoretical results were verified by using the experimental characteristics of the GS-6K and EI-437B nickel-based alloys, previously reported by other researchers.
\end{abstract}

Keywords: gas turbine engine, service life, repeated-static loading, low-cycle fatigue, creep, retention of load

Type of the work: Research Article

\section{INTRODUCTION}

Increasing of the life-cycle cost of aircraft gas turbine engines requires the implementation of efficient maintenance strategies, aimed at the maximum utilization of the potential individual life of each engine while ensuring the specified reliability. Such strategies are based on in-service engine health management - especially engine service life monitoring. One of the major problems inherent in the development of such life monitoring algorithms is that the character of loading in real flight cycles is crucially different from the character of the static and dynamic loading that occurs during testing of the samples of material.

In real flight cycles, aircraft parts are working under complex loading conditions. This complex loading consists in a combination of the major destructive types of loadings: static (at the high temperature), cyclic (high-cycle and low-cycle), and repeated-static. Under these loadings, the properties of materials manifest themselves in creep and long-term strength (LTS) and resistance to the low-cycle, high-cycle and repeated-cycle fatigue (LCF, HCF and RCF), respectively. 
The influence of different types of loading on the life of the engine parts has been discussed repeatedly in the engineering literature [e.g. 1, 11-14]. However, despite the significant practical interest and the proven generally accepted normative methods and recommendations on the problem, complex loading remains insufficiently studied.

Many studies have focused on the influence of the pair correlations of the above-mentioned components of the complex loading on the life of engine parts. Such research primarily concerns the influence of the retentions in cycle under the maximum temperature and stress on the accumulation of damage and ability of the material to support LCF, HCF and RCF. In particular, many existing papers consider linear and non-linear accumulation of the damage caused by the cyclic loading and retentions. Approaches useful for practical implementation can be found in [1], where both the efficiency of the method and the required volume of preliminary experimental studies are taken into account.

In this paper, the simple method to solve this problem is proposed, which is based on the known characteristics of material creep, LCF and RCF strength, the regularities of the repeated-cyclic loading, and linear accumulation of damage. The theoretical results are then verified against previously reported experimental characteristics.

\section{MAJOR CHARACTERISTICS OF MATERIALS UNDER REPEATED-STATIC LOADING}

The initial concept of repeated-cycle fatigue (RCF) as a common form of non-zero cyclic loading was formulated in the works of I. A. Birger, B.F. Shorr, G.B. Iosilevych and a number of other researchers. The main principles of the RCF concept in the modern view were studied by V. I. Ceytlin, N. D. Kuznetsov, D. G. Fedorchenko, Yu. M. Anurov, M. Ye. Kolotnikov [1-5], and others. They are based on the concept of coefficient $\mathrm{K}_{\mathrm{z}}$, which shows the material sensitivity to the number $\mathrm{z}$ of the repeated loadings with static stress $\sigma$ (at elevated temperatures) or, equivalently, to the number of the interruptions of such loading. This coefficient was introduced by V. I. Ceytlin [2]. At a given temperature T, the dependence for $\mathrm{K}_{\mathrm{z}}$ takes the form:

$\mathrm{K}_{\mathrm{z}}=\frac{\sigma\left(\mathrm{t}_{\mathrm{f}}\right)}{\sigma\left[\mathrm{t}_{\mathrm{f}}(\mathrm{z})\right]}$,

where $\sigma\left(t_{\mathrm{f}}\right)$ is limit of material LTS that is determined at the given temperature $T$ and time to fracture $t_{f}$ while single $(\mathrm{z}=1)$ loading using the following conventional model of LTS:

$\sigma^{\mathrm{m}} \cdot \mathrm{t}_{\mathrm{f}}=\mathrm{A}$

or in logarithmic coordinates:

$\mathrm{m} \cdot \lg \sigma+\lg \mathrm{t}_{\mathrm{f}}=\lg \mathrm{A}$

where $\mathrm{t}_{\mathrm{f}}$ and $\mathrm{t}_{\mathrm{f}}(\mathrm{z})$ are times to fracture for the stress $\sigma\left(\mathrm{t}_{\mathrm{f}}\right)$ at a single $(\mathrm{z}=1)$ and $\mathrm{z}$-fold loading, respectively; $\sigma\left[\mathrm{t}_{\mathrm{f}}(\mathrm{z})\right]$ is the material LTS limit at temperature T and time to fracture $\mathrm{t}_{\mathrm{f}}(\mathrm{z})$.

The stress $\sigma_{\mathrm{z}}\left[\mathrm{t}_{\mathrm{f}}(\mathrm{z})\right]=\sigma\left(\mathrm{t}_{\mathrm{f}}\right)$ can be qualified, in our opinion, as the limit of material RCF.

Fig. 1. shows geometric and algebraic representations that explain the physical sense of Eq. (1) and its components. Thus [2,3], it was shown that $\mathrm{K}_{\mathrm{z}}<1$ and in this case from (1) follows the inequality $\mathrm{t}_{\mathrm{f}}(\mathrm{z})<\mathrm{t}_{\mathrm{f}}$. This means that in the case of repeated-static loading (RSL), the actual durability corresponds to some conditional stress:

$\sigma\left[\mathrm{t}_{\mathrm{f}}(\mathrm{z})\right]=\frac{1}{\mathrm{~K}_{\mathrm{z}}} \cdot \sigma\left(\mathrm{t}_{\mathrm{f}}\right)>\sigma\left(\mathrm{t}_{\mathrm{f}}\right)$ 


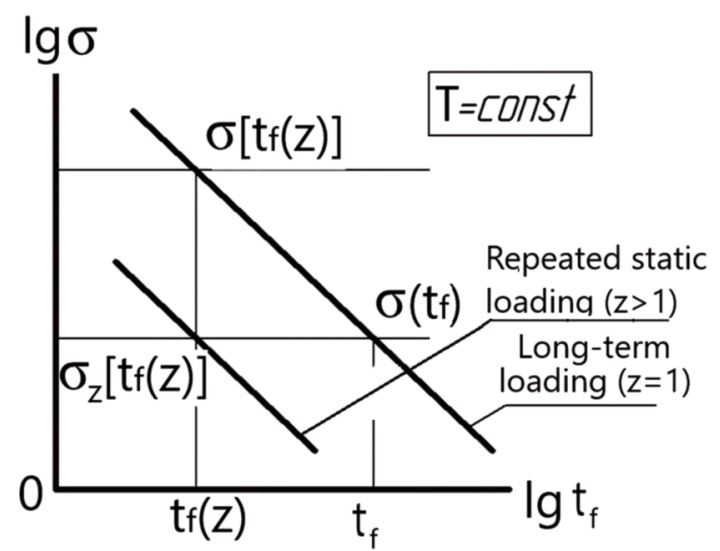

Fig. 1. Diagram of the basic model of the long-term loading (creep, $\mathrm{z}=1$ ) and its modification to the model of RSF at $\mathrm{z}>1$.

In addition, the authors of [2,3], in constructing model II (z) (Fig. 1), admitted the possibility of using a dependence similar to (2) with the same value of the parameter $\mathrm{m}$, and also they assumed that $\mathrm{m}$ in model II (z) is independent of the applied stress value $\sigma\left(\mathrm{t}_{\mathrm{f}}\right)=\sigma_{\mathrm{z}}\left[\mathrm{t}_{\mathrm{f}}(\mathrm{z})\right]$. This fact determines the parallel arrangement of the models I and II (Fig. 1); the slopes of them depend on $\mathrm{m}$.

Under these assumptions, it is possible to obtain an important relationship for the further presentation between $t_{f}(z)$ and $t_{f}$ (Fig. 1). To do so, let us explore (2) and find $t_{f}=A \cdot[\sigma]^{-m}$ and $t_{f}(z)=A \cdot\left\{\sigma_{z}\left[t_{f}\right.\right.$ $(\mathrm{z})]\}^{-\mathrm{m}}=\mathrm{A} \cdot\left[\sigma\left(\mathrm{t}_{\mathrm{f}}\right) \cdot \mathrm{K}_{\mathrm{z}}\right]^{-\mathrm{m}}$; from these equalities we obtain:

$\mathrm{t}_{\mathrm{f}}(\mathrm{z})=\mathrm{t}_{\mathrm{f}} \cdot\left[\mathrm{K}_{\mathrm{z}}\right]^{\mathrm{m}}$.

The dependence of $\mathrm{K}_{\mathrm{z}}$ on $\mathrm{z}$, which determines the main regularities of the RSL, is found from the experimentally obtained RSF models (curve II (z) in Fig. 1 is one of these models). In [5], the dependences of $\mathrm{K}_{\mathrm{z}}$ on $\mathrm{z}$ were found within the limits up to $\mathrm{z}=10^{3}$ to $10^{5}$, and these relations with sufficient accuracy were approximated by a semi-logarithmic linear equation:

$\mathrm{K}_{\mathrm{z}}=-\mathrm{k}_{1} \cdot \lg \mathrm{z}+\mathrm{k}_{2}$.

\section{LINEAR ACCUMULATION OF MATERIAL DAMAGE UNDER THE INTERACTION OF LOW-CYCLE FATIGUE AND REPEATED-CYCLIC LOADING WITH RETENTIONS IN CYCLE}

We will assume [5] that in the case under consideration, the total damage $\mathrm{D}_{\Sigma}$ is the result of a linear summation of two components of damage:

$\mathrm{D}_{\mathrm{LCF}}=\frac{\mathrm{z}}{\mathrm{z}_{\mathrm{f}}}$, called the zero-to-tension $(\mathrm{r}=0)$ triangular cycle of low-cycle loading, and

$\mathrm{D}_{\mathrm{RSF}}=\frac{\tau_{\Sigma}}{\mathrm{t}_{\mathrm{f}}(\mathrm{z})}$, called RSL with retentions $\tau_{\mathrm{r}}$ at each loading interrupt;

total duration of retentions is $t_{\Sigma}=\mathrm{z} \cdot \tau_{\mathrm{r}}$. Here $\mathrm{z}$ is the number of the triangular cycles of the low-cycle loading and, at the same time, the number of the loading interruptions in the RSL; $\mathrm{z}_{\mathrm{f}}$ is the number of the triangular cycles before destruction; $\mathrm{t}_{\mathrm{f}}(\mathrm{z})$ is the total duration of retentions until fracture, taking into account the load interruptions in the RSL. 
The condition of the material fracture under the indicated complex loading, taking into account relation (5), can be written in the form:

$$
\mathrm{D}_{\Sigma}=\mathrm{D}_{\mathrm{LCF}}+\mathrm{D}_{\mathrm{RSF}}=\frac{\mathrm{z}_{\mathrm{i} \Sigma}}{\mathrm{Z}_{\mathrm{f}}}+\frac{\mathrm{z}_{\mathrm{i} \Sigma} \times \tau_{\mathrm{r}}}{\mathrm{t}_{\mathrm{f}} \times\left[\mathrm{K}_{\mathrm{z}}\right]^{\mathrm{m}}} \geq 1,
$$

where $z_{i} \Sigma$ is the number of cycles (with retentions $\tau_{\mathrm{r}}$ in each cycle) until fracture, which depends on the same values of $\sigma\left(\mathrm{t}_{\mathrm{f}}\right)$ and $\sigma$, temperature $\mathrm{T}$ and duration of retentions $\tau_{\mathrm{r}}$.

Whereby:

- $\mathrm{z}_{\mathrm{f}}$ is determined by models of the material LCF under soft loading, depending on the stress range and working temperature $\mathrm{T}$;

- $\sigma\left(t_{\mathrm{f}}\right)$ is determined from the original LTS model (2) (curve I $(\mathrm{z}=1)$ in Fig. 1).

\section{INITIAL DATA}

Model studies of the cycle retention effect on the material LCF were carried out for the heat-resistant alloys EI-437B and GS-6K (known by the Cyrillic designations ЭИ-437Б and ЖС-6К) using the following set of strength characteristics (at the same operating temperatures $\mathrm{T}$ ):

1) initial LTS models $(z=1)$;

2) LCF models for a zero-to-tension triangular cycle;

3) LTS models with z-fold loading interruption or, equivalently, RSF models;

4) dependences of $\mathrm{K}_{\mathrm{z}}$ on the retention number $\mathrm{z}$.

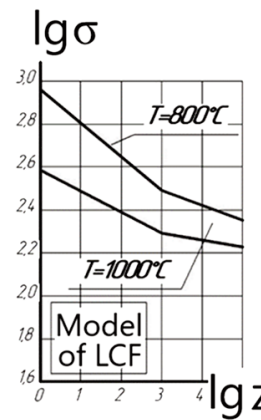

(a)

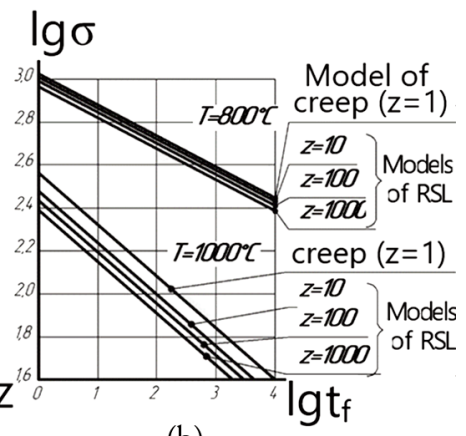

(b)

Fig. 2. Diagrams of LCF (a), creep and RSF at $\mathrm{z}>1$ (b)

for the alloy GS-6K under the temperature $800^{\circ} \mathrm{C}$ and $1000^{\circ} \mathrm{C}$.

From the technical literature, we have selected complete characteristic sets for the indicated alloys and the following operating temperatures: for the EI-437B alloy - at $750^{\circ} \mathrm{C}$, and for the GS-6K alloy - at $800^{\circ} \mathrm{C}$ and $1000^{\circ} \mathrm{C}$. These characteristics are shown in Fig. 2-4.

Material characteristics shown in Fig. 2-4 were approximated for use in Eq. (7) as follows:

1. Values $\sigma$ for the corresponding $\mathrm{t}_{\mathrm{f}}$ and $\mathrm{T}$ given in [6] in tabular data are generalized in the form of the Larson-Miller model. Subsequently, for the alloys GS-6K (working temperatures $800^{\circ} \mathrm{C}$ and $1000^{\circ} \mathrm{C}$ ) and $\mathrm{EI}-437 \mathrm{~B}\left(750^{\circ} \mathrm{C}\right)$, we found the parameters $\mathrm{m}(\mathrm{T})$ and $\mathrm{A}(\mathrm{T})$ of LTS model (2) using the common method, arriving at $\mathrm{m}(\mathrm{T})=7.1 ; 3.71 ; 6.35$ and $\mathrm{A}(\mathrm{T})=2.51 \cdot 10^{21} ; 3.98 \cdot 10^{9} ; 4.57 \cdot 10^{17}$ respectively.

2. The following data on the symmetric triangular cycle were used as LCF characteristics: for GS-6K according to [7] and for EI-437B according to [8]. The procedure described in [9] was used for the transition to the zero-to-tension cycle. 


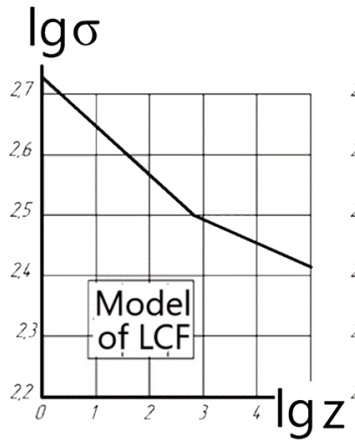

(a)

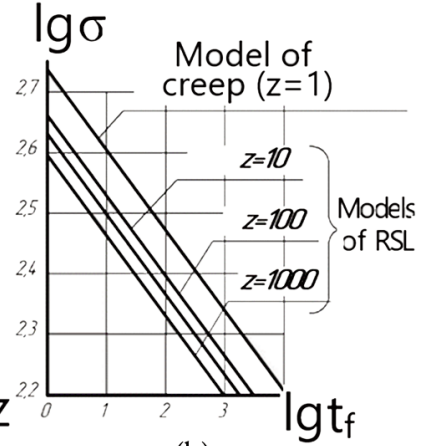

(b)

Fig. 3. Diagrams of LCF (a), creep and RSF at $\mathrm{z}>1$ (b) for the alloy EI-437B under the temperature $750^{\circ} \mathrm{C}$.

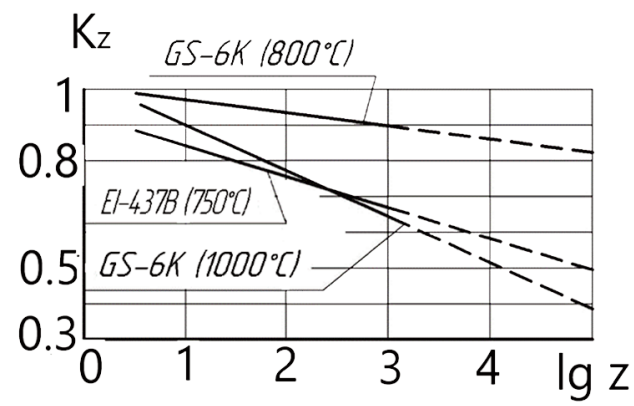

Fig. 4. Coefficient $\mathrm{K}_{\mathrm{z}}$ versus the number of loading interrupts $\mathrm{z}$ for the alloys GS-6K and EI-437B.

Since the graphs of the LCF in logarithmic coordinates have inflections in the region $\mathrm{z} \approx 1 \cdot 10^{3}$, for use in (6), we adopted the LCF model under soft loading in the following form:

$(\sigma)^{\mathrm{M}_{\mathrm{j}}(\mathrm{T})} \cdot \mathrm{z}=\mathrm{C}_{\mathrm{j}}(\mathrm{T}), \mathrm{j}=1,2$.

The parameters $M_{j}(T)$ and $C_{j}(T)$ were determined from the specified initial data using the leastsquares method. The results of their calculation are shown in Table 1.

Tab. 1. Parameters of the models of LCF (8) and RCF (6)

\begin{tabular}{|c|c|c|c|c|}
\hline Material & $\mathrm{T},{ }^{\circ} \mathrm{C}$ & $\mathrm{M}_{1} / \mathrm{M}_{2}$ & $\frac{\mathrm{C}_{1}}{\mathrm{C}_{2}}$ & $\mathrm{k}_{1} / \mathrm{k}_{2}$ \\
\hline \multirow{2}{*}{ GS-6K } & 800 & $5.49 / 30.9$ & $\frac{1.87 \cdot 10^{16}}{6.72 \cdot 10^{77}}$ & $0.03 / 0.98$ \\
\cline { 2 - 5 } & 1000 & $8.32 / 14.1$ & $\frac{5.41 \cdot 10^{22}}{3.95 \cdot 10^{36}}$ & $0.08 / 0.91$ \\
\hline EI-437B & 750 & $10.3 / 14.2$ & $\frac{2.15 \cdot 10^{29}}{1.46 \cdot 10^{39}}$ & $0.08 / 0.91$ \\
\hline
\end{tabular}

3. To approximate the dependence of $\mathrm{K}_{\mathrm{z}}$ on $\mathrm{z}$, we used model (6) with parameters $\mathrm{k}_{1}$ and $\mathrm{k}_{2}$ taken from [5], according to Table 1 . 
By substituting all the above approximations of material characteristics into formula (7), we obtain the following nonlinear equation for summing the damages:

$\frac{\mathrm{z}_{\mathrm{i} \Sigma} \cdot(\sigma)^{\mathrm{M}_{\mathrm{j}}(\mathrm{T})}}{\mathrm{C}_{\mathrm{j}}(\mathrm{T})}+\frac{\mathrm{z}_{\mathrm{i} \Sigma} \cdot \tau_{\mathrm{r}} \cdot \sigma^{\mathrm{m}}}{\mathrm{A}(\mathrm{T})\left(\mathrm{k}_{2}-\mathrm{k}_{1} \lg \mathrm{z}_{\mathrm{i} \Sigma}\right)}=1$.

By numerically solving this equation, it is possible to determine the number of cycles $\mathrm{z}_{\mathrm{i} \Sigma}$ until fracture for various retentions $\tau_{\mathrm{r}}$, taking into account the combined action of the LCF and RSL with retentions, as well as the values of damage $\mathrm{D}_{\mathrm{LCF}}$ and $\mathrm{D}_{\mathrm{RCF}}$.

\section{INFLUENCE OF CYCLE RETENTION ON THE LCF OF ALLOYS GS-6K AND EI-437B}

\subsection{Method of research}

The research methodology is based on solutions of equation (9) with respect to $z_{i} \Sigma$ at various values of retentions $\tau_{\mathrm{r}}$.

The solution of the nonlinear equation (9) was carried out using the Excel parameter selecting function. A preliminary confirmation of the method's high accuracy was obtained using the well-known method of half division, with software implemented in the $\mathrm{C}++$ language.

Let us consider the method based on the example of one of the main research cases - for the GS-6K alloy at $\mathrm{T}=1000^{\circ} \mathrm{C}$. For this case, Table 2 shows a variant of calculating $\mathrm{z}_{\mathrm{i} \Sigma}$, damage components $\mathrm{D}_{\mathrm{LCF}}$ and $D_{\mathrm{RSF}}$, as well as their ratio $\Psi=\frac{\mathrm{D}_{\mathrm{RSF}}}{\mathrm{D}_{\mathrm{LCF}}}$ for the GS-6K alloy at $1000^{\circ} \mathrm{C}$ for several characteristic values of retention $\tau_{\mathrm{r}}$. The column order in the table corresponds to the sequence of obtaining solutions from equation (9).

Fig. 5 shows the corresponding graphical dependencies, and Fig. 6 shows dependence of the coefficient $\Psi$ on the values of $\mathrm{z}_{\mathrm{i} \Sigma}$.

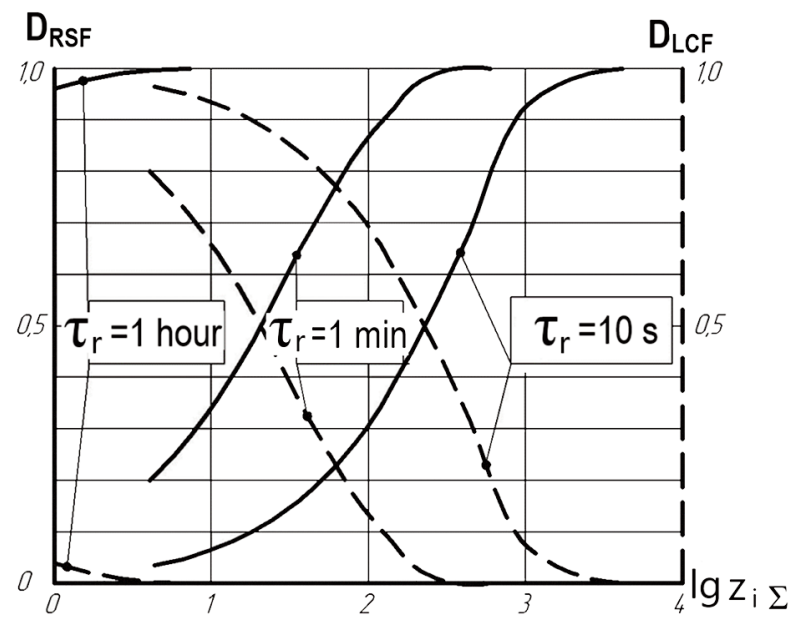

Fig. 5. Values of damage $\mathrm{D}_{\mathrm{RCF}}$ and $\mathrm{D}_{\mathrm{LCF}}$ (dotted lines) for the alloy GS- $6 \mathrm{~K}\left(1000^{\circ} \mathrm{C}\right)$. 
Tab. 2. Numerically determined parameters $z_{\mathrm{i} \Sigma}, \mathrm{D}_{\mathrm{LCF}}, \mathrm{D}_{\mathrm{RCF}}$, and $\Psi$ for the alloy GS-6K $\left(1000^{\circ} \mathrm{C}\right)$.

\begin{tabular}{|c|c|c|c|c|c|c|c|c|}
\hline$\sigma, \mathrm{MPa}$ & $\tau_{r}, h$ & $t_{f}, h$ & $\mathrm{Kz}$ & $t_{\mathrm{f}}(\mathrm{z}), \mathrm{h}$ & $\mathrm{z}$, cycles & $\mathrm{D}_{\mathrm{RSF}}$ & $\mathrm{D}_{\mathrm{LCF}}$ & $\Psi$ \\
\hline 200 & \multirow{5}{*}{$\begin{array}{l}0.0028 \\
(1 \mathrm{sec})\end{array}$} & 11.61 & 0.674 & 2.69 & 883 & 0.911 & 0.089 & 10.28 \\
\hline 250 & & 5.07 & 0.714 & 1.45 & 281 & 0.537 & 0.463 & 1.157 \\
\hline 300 & & 2.58 & 0.752 & 0.9 & 94 & 0.292 & 0.708 & 0.4123 \\
\hline 350 & & 1.46 & 0.79 & 0.61 & 32 & 0.144 & 0.856 & 0.1687 \\
\hline 400 & & 0.87 & 0.826 & 0.44 & 11 & 0.072 & 0.928 & 0.0774 \\
\hline 150 & \multirow{6}{*}{$\begin{array}{l}0.0167 \\
(1 \mathrm{~min})\end{array}$} & 33.74 & 0.693 & 8.65 & 518 & 0.999 & 0.001 & 995.3 \\
\hline 200 & & 11.61 & 0.725 & 3.52 & 207 & 0.979 & 0.021 & 47.2 \\
\hline 250 & & 5.07 & 0.753 & 1.77 & 91 & 0.851 & 0.149 & 5.694 \\
\hline 300 & & 2.58 & 0.78 & 1.03 & 42 & 0.684 & 0.316 & 2.16 \\
\hline 350 & & 1.46 & 0.808 & 0.66 & 19 & 0.483 & 0.517 & 0.9334 \\
\hline 400 & & 0.87 & 0.836 & 0.46 & 8 & 0.307 & 0.693 & 0.4436 \\
\hline 100 & \multirow{6}{*}{$\begin{array}{l}0.0833 \\
(5 \mathrm{~min})\end{array}$} & 151.87 & 0.696 & 39.56 & 475 & 1 & 0 & 301238 \\
\hline 150 & & 33.74 & 0.74 & 11.05 & 133 & 1 & 0 & 3894 \\
\hline 200 & & 11.61 & 0.772 & 4.44 & 53 & 0.995 & 0.005 & 186.7 \\
\hline 250 & & 5.07 & 0.798 & 2.19 & 25 & 0.959 & 0.041 & 23.02 \\
\hline 300 & & 2.58 & 0.82 & 1.23 & 13 & 0.899 & 0.101 & 8.974 \\
\hline 350 & & 1.46 & 0.841 & 0.76 & 7 & 0.801 & 0.199 & 4.02 \\
\hline 100 & \multirow{4}{*}{1} & 151.87 & 0.769 & 57.39 & 57 & 1 & 0 & 2491692 \\
\hline 150 & & 33.74 & 0.814 & 15.74. & 16 & 1 & 0 & 32806 \\
\hline 200 & & 11.61 & 0.846 & 6.25 & 6 & 0.999 & 0.001 & 1593.3 \\
\hline 250 & & 5.07 & 0.871 & 3.04 & 3 & 0.996 & 0.004 & 199.1 \\
\hline
\end{tabular}

$\lg \Psi$

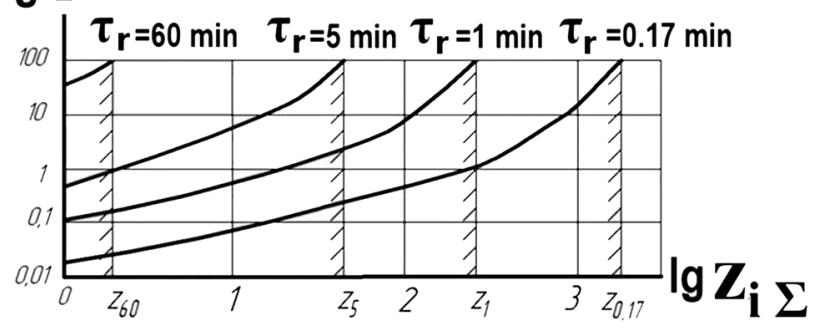

Fig. 6. Relative damage $\Psi$ versus the number of cycles to fracture and durability of cycle retentions for the alloy GS-6K $\left(1000^{\circ} \mathrm{C}\right)$.

The graph in Fig. 5 represents the characteristic points $\mathrm{z}_{60}, \mathrm{z}_{5}, \mathrm{z}_{1}$ and $\mathrm{z}_{0.17}$ for the corresponding values of the retentions in the cycle, which are the final region boundaries (along the $z_{i} \Sigma$ axis) of $D_{L C F}$ influence (at least $1 \%$ of $\mathrm{D}_{\mathrm{RCF}}$ ) and the initial region boundaries of complete prevalence of $\mathrm{D}_{\mathrm{RSF}}$, in which $\mathrm{D}_{\mathrm{LCF}}<0.01$ of $\mathrm{D}_{\mathrm{RSF}}$. For the case under consideration, with retention $\tau_{\mathrm{r}}=0.17 \mathrm{~min}$, $\mathrm{z}_{0.17}=1778$ cycles; $1 \mathrm{~min}-\mathrm{z}_{1}=270$ cycles; $5 \mathrm{~min}-\mathrm{z}_{5}=44$ cycles; $60 \mathrm{~min}-\mathrm{z}_{60}=2$ cycles, which means significant expansion of the region (along the $\mathrm{z}_{\mathrm{i} \Sigma}$ axis) of the prevailing role of $\mathrm{D}_{\mathrm{RSF}}$.

Thus, the function $\Psi$ is very convenient for quantitative representations and assessments of the influence of $\mathrm{D}_{\mathrm{LCF}}$ and $\mathrm{D}_{\mathrm{RCF}}$, as well as factors of the phenomenon under consideration (type of material and its characteristics, operating temperature, retention value $\tau_{\mathrm{r}}$ in the loading cycle, etc.), on the material durability $z_{i} \Sigma$. 


\subsection{Results of research}

In addition to the above case $\left(\mathrm{GS}-6 \mathrm{~K}\right.$ at $\left.\mathrm{T}=1000^{\circ} \mathrm{C}\right)$, the cases for the $\mathrm{GS}-6 \mathrm{~K}$ alloys at $800^{\circ} \mathrm{C}$ and $\mathrm{EI}-437 \mathrm{~B}$ at $750^{\circ} \mathrm{C}$ were considered. The results are shown in Fig. $7-8$ in the form of the dependence of $\Psi$ on $z_{\mathrm{i} \Sigma}$.

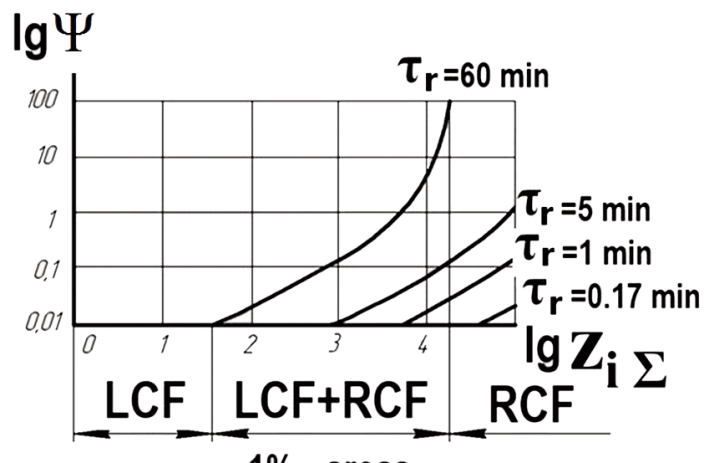

$1 \%$ - areas

Fig. 7. Relative damage $\Psi$ versus the number of cycles to fracture and durability of the retentions in cycle for the alloy GS-6K $\left(800^{\circ} \mathrm{C}\right)$.

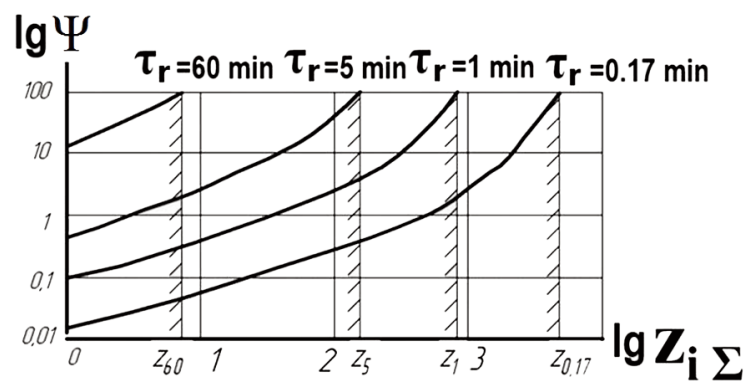

Fig. 8. Relative damage $\Psi$ versus the number of cycles to fracture and durability of the retentions in cycle for the alloy GS-6K $\left(750^{\circ} \mathrm{C}\right)$.

Comparative analysis shows that for the EI- $437 \mathrm{~B}$ alloy $\left(750^{\circ} \mathrm{C}\right)($ Fig. 8$)$, the $\mathrm{D}_{\mathrm{RSF}}$ prevalence region, although shifted to the side of large $\mathrm{z}_{\mathrm{i} \Sigma}$, remains similar for the case of $\mathrm{GS}-6 \mathrm{~K}\left(1000^{\circ} \mathrm{C}\right)$. For the case of GS-6K $\left(800^{\circ} \mathrm{C}\right)$ (Fig. 7), the nature of the functions $\Psi$ for different retention values changes significantly, shifting (along the $\mathrm{z}_{\mathrm{i} \Sigma}$ axis) to the HCF region to $\mathrm{z}_{\mathrm{i} \Sigma}=10^{7} \ldots 10^{8}$, which was not considered in this study due to insufficient information about the dependence of $\mathrm{K}_{\mathrm{z}}$ on $\mathrm{z}$, limited by the values of $\mathrm{z}=10^{3} \ldots 10^{5}$.

Using the proposed method, we made adjustments to the known LCF characteristics (Fig. 3, a and Fig. 3, b) for the three cases under consideration, taking into account the influence of retention duration (in the low-cycle loading cycle at maximum stresses and temperatures) on $\mathrm{z}_{\mathrm{i} \Sigma}$. Fig. 9 shows an example of corresponding LCF curves of the EI-437B alloy at $\mathrm{T}=750^{\circ} \mathrm{C}$ for certain values of $\tau_{\mathrm{r}}$. 


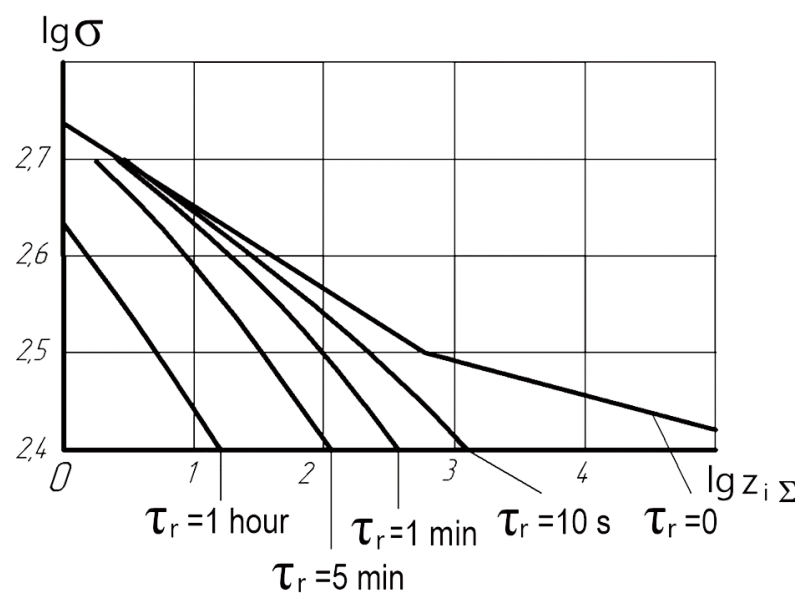

Fig. 9. LCF diagrams for the alloy EI-437B at $750^{\circ} \mathrm{C}$ under several durability of the retentions $\tau_{\mathrm{r}}$.

\subsection{Comparison of theoretical and experimental data}

For comparison, we used experimental data drawn from study [10] on the EI-437B alloy at a temperature of $\mathrm{T}=750^{\circ} \mathrm{C}$, shown in Fig. 10 . They show the nature of the deviations from the vertical lines $\lg \mathrm{z}\left(\mathrm{T}_{\mathrm{i}}\right)=$ const or decreasing of initial $\left(\right.$ at $\left.\tau_{\mathrm{r}}=0\right)$ values while exhibiting retentions $\tau_{\mathrm{r}}$ in the lowcycle loading cycle.

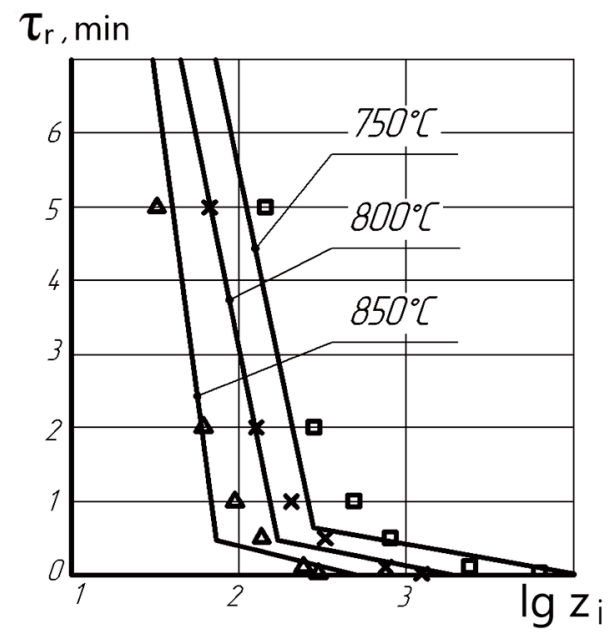

Fig. 10. The number of interrupts $z_{i}(\sigma, T)$ versus retention durability $\tau_{\mathrm{r}}$ for the alloy EI-437B [5]; the points are determined using the proposed model of the damage accumulation: $\boldsymbol{\Lambda}-\sigma=400 \mathrm{MPa}$, - $-\sigma=350 \mathrm{MPa}, \boldsymbol{\square}-\sigma=300 \mathrm{MPa}$. 
We obtained the calculated values of $\mathrm{z}_{\mathrm{i} \Sigma}$ for the temperature $\mathrm{T}=750^{\circ} \mathrm{C}$ shown on the graph in full accordance with the characteristics set of the EI-437B alloy for this temperature. When obtaining the calculated values for temperatures of $800^{\circ} \mathrm{C}$ and $1000^{\circ} \mathrm{C}$, we predicted the necessary characteristics were predicted on the basis of data for a temperature of $750^{\circ} \mathrm{C}$. In general, a high level of qualitative and quantitative agreement between the results of experiments and calculations can be noted.

\section{CONCLUSIONS}

1. This paper proposes a method for taking into account the effect of retentions at maximum stresses and cycle temperatures on LCF, using the laws of the RSL and linear summation of damage from lowcycle triangular-shaped zero-to-tension cycle loading and RSL with retentions of different duration.

2. A nonlinear equation for the summation of these damages is obtained, and a method for its solution is proposed with respect to the resulting number of cycles until fracture $\mathrm{z}_{\mathrm{i} \Sigma}$ and damage components $\mathrm{D}_{\mathrm{LCF}}$ and $\mathrm{D}_{\mathrm{RCF}}$.

3. The dependence $\Psi=\frac{D_{R S F}}{D_{L C F}}$ on $z_{i}$ is proposed as an effective indicator of the mutual influence of damage components under various loading factors.

4. The proposed method is fully implemented for high-temperature alloys GS-6K at operating temperatures of $800^{\circ} \mathrm{C}$ and $1000^{\circ} \mathrm{C}$ and $\mathrm{EI}-437 \mathrm{~B}$ at a temperature of $750^{\circ} \mathrm{C}$.

5. For the EI-437B alloy, good quantitative and qualitative agreement was found between data from the experimental literature data and calculations made by the proposed method.

\section{REFERENCES}

[1] Kolotnikov, M.Ye., 2003, "Predel'noe sostoyanie i prognozirovanie resursa GTD v usloviyah mnogokomponentnogo nagruzheniya" [Marginal State and Life Prediction of GTE Under MultiComponent Loading. Edited by V.M. Chepkin], Rybinsk State Aviation Engineering Academy, Rybinsk.

[2] Ceytlin, V.I., 1974, "Ocenka prochnosti detalej v usloviyah mnogokomponentnogo nagruzheniya" [Strength of Parts Estimation Under Multi-Component Loading Conditions], Aero Gas Turbine Engines Designing and Development, Issue 67, pp. 123-131.

[3] Kuznetsov, N.D., and Ceytlin, V.I., 1976, Ekvivalentnye ispytaniya gazoturbinnyh dvigatelej [Equivalent Testing of Gas Turbine Engines], Mechanical Engineering Publishing, Moscow.

[4] Ceytlin, V.I., and Fedorchenko, D.G., 1983, "Ocenka ciklicheskoj dolgovechnosti detalej, rabotayushchih pri slozhnyh programmah nagruzheniya" [Estimation of Cyclic Durability of the Parts that Operate Under Complex Loading Programs], Problems of Strength, 2, pp. 13-19.

[5] Anurov, Yu.M., and Fedorchenko, D.G., 2004, "Osnovy obespecheniya prochnostnoj nadezhnosti aviacionnyh dvigatelej i silovyh ustanovok" [Bases of Strength Reliability of Aero Engines and Power Plants], Saint-Petersburg State Polytechnic University, Saint-Petersburg.

[6] Birger, I.A., Shorr, B.F., and Iosilevych, G.B., 1979, Raschet na prochnost' detalej mashin [Strength Analysis of Machine Elements], Mechanical Engineering Publishing, Moscow.

[7] Sinayskii, B.N., Pogrebnyak, A.D., and Ischenko, I.I., 1976, "O temperaturnoj zavisimosti ustalostnoj prochnosti zharoprochnyh nikelevyh splavov" [About Temperature Relation of Heat-Resistant Nickelbase Alloys], Problems of Strength, 5, pp. 13-18.

[8] Orlov, A.F., Balashov, B.F., 1990, "Nekotorye osobennosti nakopleniya povrezhdenij dlya GTD pri malociklovom nagruzhenii i povyshennyh temperaturah" [Several Peculiarities of Damage Accumulation 
for GTE Under Lo-Cyclic Loading and High Temperature], Low-Cycle Fatigue of Structural Elements, III All-Union Symposium, pp. 45-54.

[9] Balashov, B.F., Birger I.A., Bychkov, N.G. et. al., 1990, "Resursnoe proektirovanie aviacionnyh GTD. Rukovodstvo dlya konstruktorov" [Life-Time Designing of Aero Engines. Designer's Textbook], Central Institute of Aero Engines, Moscow, Issue 1.

[10] Birger, I.A., Shorr B.F., 1975, Termoprochnost' detalej mashin [Thermal Strength of Machine Elements], Mechanical Engineering Publishing, Moscow.

[11] He, J., Sandstrom, R., and Vujic, S., 2016, "Creep, low cycle fatigue and creep-fatigue properties of a modified HR3C”, $21^{\text {st }}$ European Conference on Fracture, ECF21, 20-24 June 2016, Catania, Italy.

[12] Porter, A.M., Bukatii, S.A., and Vodolagin, A.L., 2009, "Issledovanie vliyaniya dlitel'nosti dejstviya maksimal'nyh napryazhenij $v$ cikle nagruzheniya na malociklovuyu ustalost' $i$ dlitel'nuyu prochnost' vala GTD iz materiala EI 961-SH" [Investigation of influence of maximum stresses action duration in loading cycle on the low-cyclic fatigue and long-term strength of gas turbine engine shaft made of EI 961-Sh material], Bulletin of Samara State Aerospace University, 3(19), pp. 56-63.

[13] Bukatii, S.A., and Okrugin, A.A., 2014, "Issledovanie ciklicheskoj dolgovechnosti materiala v usloviyah malociklovoj ustalosti i dlitel'noj prochnosti" [Investigation of material cyclic durability under conditions of low-cycle fatigue and long-term strength], Bulletin of Samara State Aerospace University, 5(47), pp. 72-77.

[14] Sheremetev, A.V., 2018, "Ob uchete mnogokomponentnogo nagruzheniya pri obespechenii prochnostnoj nadezhnosti detalej aviacionnyh GTD” [About the calculation of polycomponent loading at the providing strength reliability of the aviation GTE components], Bulletin of Engine Design, 2, pp. 164-169.

\title{
WPŁYW RETENCJI OBCIĄŻENIA NA ELEMENTY SILNIKA LOTNICZEGO W WARUNKACH RZECZYWISTYCH CYKLI LOTNICZYCH W MONITOROWANIU TRWAŁOŚCI EKSPLOATACYJNEJ
}

\begin{abstract}
Abstrakt
Jednym z głównych problemów w opracowywaniu algorytmów do monitorowania trwałości lotniczych gazowych silników turbinowych jest to, że charakter obciążeń powstałych w rzeczywistych cyklach lotu różni się zasadniczo od charakteru obciążeń statycznych i dynamicznych obecnych podczas testowania próbek. W niniejszej pracy zaproponowano metodę pozwalającą uwzględnić wpływ retencji przy maksymalnych naprężeniach oraz temperatur cyklicznych na zmęczenie niskocyklowe (LCF) stopów żaroodpornych używanych w elementach silnika. Wykorzystano regularności w powtarzalnym obciążeniu statycznym (RSL) w połączeniu z metodą linearnej akumulacji uszkodzeń wynikających ze zmęczenia niskocyklowego i powtarzalnego obciążenia statycznego, z retencjami o zmiennej długości. Dla sumowania tych uszkodzeń wyprowadzono nieliniowe równanie, którego rozwiązanie określa trwałość (żywotność) elementu z uwzględnieniem czasu trwania retencji. Wyniki teoretyczne zostały zweryfikowane na podstawie charakterystyk doświadczalnych stopów na bazie niklu GS-6K i EI-437B, zaczerpniętych z wcześniejszych prac innych zespołów badawczych.
\end{abstract}

Słowa kluczowe: gazowy silnik turbinowy, żywotność serwisowa, powtarzalne obciążenie statyczne, zmęczenie niskocyklowe, pełzanie, retencja obciążenia 